\title{
A Brief History of the Idea of the State of Law and Its Basic Indicators
}

Nguyen Thi Hoi

\section{A Brief History of the Idea of the State of Law}

In the history of legal and political ideas of humankind, the idea of legal dominance over a state and society and the notion of a state that rules and controls by law and maintains legal observance werecreated at a time as early as the prehistorical period. The foundation of these ideas is closely tied to the rise of popular sovereignty and democracy as opposed to authoritarian and tyrant individual rulers as well as anarchy and unlawfulness, and requires the state and the society as a whole to depend on law. This is reflected in the ideas of well-known Western and Eastern thinkers.

In the West, the idea of the state of law was founded at an early time and reflected in the works of thinkers and political activities of statesmen. This becomes more apparent when we take a glimpse at the viewpoints of thinkers whose ideas have been famous for many centuries. Solon (c. 638-c. 559 B.C.) was a renowned Greek sophist, poet, legislator and political activist at premodern history. In 594 B.C., having been appointed as archon of Athens, Solon passed a number of laws to reform state and society. These included a land reform to return to farmers their lands previously used as mortgages, a slavery reform that gave back bonded slaves their freedom, a class reform to define the rights and responsibilities of each class, and a legislation on the founding of a People's Assembly (ecclesia) and a People's Court (heliala). The introduction of these laws confirmed that Solon was well aware of the role of laws in social governance and control, as he stated that internal peace was based on a firm 
state and a legal system. ${ }^{1}$ He wrote: "Anarchy would generate tons of disasters and bring about the extinction of the city. Only the law is able to establish order and construct unison."

Heraclitus (c. 530-470 B.C.) - the great Greek materialist philosopher, who upheld the law and considered it a means to realize universal harmony, also emphasizes the role of written law and its protection and consolidation. For him, cities are bound to be founded on a legal basis and the law has to be fought for as much as the stability of one's home city. ${ }^{3}$

Socrates (469-399 B.C.), the renowned Greek orator, says that every citizen who has settled in a nation is to be bound by a contract by which he maintains absolute adherence to the law, however good or bad it is. A society cannot function well without efficient laws. The most sacred value is justice, which means to live according to the public law. ${ }^{4}$

Platon (427-347 B.C.), the prominent ancient Greek philosopher and also Socrates' most loyal student, maintains that the state can exist as long as public authorities completely observe the law. He claims to foresee the extinction of the state wherever the law is inefficient and inferior to any personal power. In contrast, wherever the law is superior to the state and public authorities are but its minions, the state and its interests are saved. ${ }^{5}$

Aristotle (384-322 B.C.) is the greatest ancient Greek "encyclopédiste" who is referred to by Karl Marx as the most influential ancient thinker. Friedrich Engels considered him as having the most complete mind among all Greek philosophers. Aristotle states that the law clearly reflects the state's role as it helps to confirm and consolidate civil rights. The law is tasked with facilitating the process by which individuals learn their rights through their relationships. However, there is no right to equalize the members of the society; differences among the rich and the poor necessarily exist. The law is divided by Aristotle into general (natural) law and particular (nationally-bound) laws. The general law is superior to particular laws. In every particular law there are also first the laws that deal with the establishment and organization of city-states

\footnotetext{
${ }^{1}$ See VNU Press (2009).

${ }^{2}$ See Luu Kien Thanh/Pham Hong Thai (1993), 62.

${ }^{3}$ Ibid.

${ }^{4}$ Ibid.

${ }^{5}$ Ibid.
} 
and those that are subordinate to the former. The legal totality makes up political justice which only exists among free and equal people. Aristotle considers legal norms "justice" and to act justly means to follow the laws. Accordingly, he deems states whose authorities rule by law and genuinely in the public interest, pure or original states, while those that favor individual will at the expense of the law and rule only for the sake of individual authorities are corrupt or phony. Regarding the state apparatus, he splits it into three sectors or segments which respectively deal with legislation or decision-making, executive or legal enforcement and jurisdiction or legal judgments. He writes: "Now there are three things in all states which a careful legislator ought well to consider, which are of great consequence to all, and which properly attended to the state must necessarily be happy; and according to the variation of which the one will differ from the other. The first of these is the public assembly; the second the officers of the state, that is, who they ought to be, and with what power they should be entrusted, and in what manner they should be appointed; the third, the judicial department."

In the East the supremacy of the law and the requirement that everyone, including the king, his officials and citizens, has to abide by the law is also manifested in the works of many ancient thinkers.

Kautilya (around the $4^{\text {th }}$ century B.C.) was a chancellor of the powerful Maurya dynasty which is credited with developing a united, wealthy and influential ancient India and was a teacher and friend of King Chandra Gupta. He proposed a plan for national construction based on a stable and ordered society, prosperous economy, formidable army and expanded influence. According to him, for a country to prosper it is first and foremost necessary to establish social order, which requires the first and fundamental role and responsibilities of the king and those of his citizens. However, in order to maintain a lasting reign the king must rule by law and resolutely adhere to it. He advised the king: "However, despite one's position as ruler of a nation, one is not allowed to act according to one's own will. To mobilize popular support for the cause national construction the king is supposed to uphold the law and strictly adhere to public norms. To rule a nation without regard to the law means to give up one's throne without any popular coup."

\footnotetext{
${ }^{6}$ Ellis (1941), Aristotle, 132.

7 Thích Mãn Giác (1967), 163.
} 
Han Fei (c. 280-233 B.C.) - a prominent representative of the legalistic school, states that the rule by law is necessarily a must for his time. He writes:

"There is no fixed way to rule the people, so it is better to resort to the law. The law has to adapt itself to each particular era, and to be efficient it must be guided by that particular era (...) a ruling principle of wise men is to adapt the law to historical circumstances and make the legislation relevant to historical conditions. ${ }^{\text {"s }}$

He therefore not only emphasizes the state of law but also calls for the objective adjustment of the law according to each historical era. In addition, he requires everyone, not excluding the king and his officials, to respect and uphold the law; Han Fei supports the equal distribution of law to everyone. He says: "Do whatever is legal and abandon whatever is illegal." Or in another version:

"Thus a lucid king is able to divert his followers from living outside the law, refusing to make good deeds within the law and committing illegal acts. The law is what forbids individual misdeeds to go beyond legal boundaries (...) the king is without safety if the law is unstable, and evil deeds are triumphant without resolute punishments. The law refuses to favor the noble born, just as the plumb-line does not yield to curves. What is assigned by the law, the wise cannot decline and the brave dare not challenge. In applying the law to transgressions, one does not tolerate great ministers; in rewarding good conduct, one does not ignore commoners. Therefore, it is nothing but the law that is capable of correcting ministers' wrongdoings, disciplining commoners' misconducts, removing chaos, righting the wrong and uniting the people's lines. "10

The above viewpoints show that in ancient ideas on the state and law, the state of law - which is ruled and controlled through legal means, supports the role of the law, respects and adheres to it and considers it an indispensable part of social management - is present. In the "dark ages" humankind had to tolerate the brutal suppression by authoritative monarchies and religiously-fanatical theocracies and live under the domination of feudal regimes - with little or nothing related to the state of law. ${ }^{11}$ In Europe

"the missionaries transformed political science and jurisprudence into nothing but the sciences that served theology, and dominant theological principles were jammed into

\footnotetext{
${ }^{8}$ Lã Trấn Vũ (1964), 283.

${ }^{9}$ Lã Trấn Vũ (1964), 288.

${ }^{10}$ Phan Ngoc (2001), 61 ff.

${ }^{11}$ See Dao Tri Uc (2006).
} 
the two former. The teachings of Congregations were at the same time political determinants and religious texts retained as much effect before the court as the law. "12

Such conditions render democracy, the supreme role of the law and legal compliance, the supreme role of citizens underdeveloped. It was not until the emergence of the capitalist mode of production and the introduction and development of humanism that the idea of the state of law reemerged, as can be seen in different ideas on the state and law by some Western scholars.

Machiavelli (1469-1527), an Italian politician and thinker says that the people are above the prince, since they are better at picking public officials than him, "the people are at all times more prudent, determined and rational than the king." ${ }^{33}$ Machiavelli sides with the people, as he argues that a king who can do whatever he wants will become an insane autocrat, and if people can do whatever they want, they will only become mad men. Therefore, the people are better than the king under a legal system; for if unbounded by the law they are likely to commit fewer wrongdoings than the king and are more predisposed to redeeming themselves. This is because any citizen who is corrupted, debased and rebellious can easily listen to advice and return to his right way; while a tyrant king can be stopped by nothing, and it takes nothing other than weapons to let him redo what is wrong. ${ }^{14}$

But more importantly, what is significant is that a legal document that reflects the state of law was created even prior to the Renaissance, the Magna Carta (Great Charter), since it carries the idea of a state that is bounded by the law. The Charter was issued in June, 1215, recognized by King John of England and improved by Edward I in 1297, and can be considered the first important legal document which legitimatized the State of England as a sovereign state of law. The Charter regulated:

"No free man is eligible to being captured or imprisoned, being deprived of his rights and properties, being turned outlaw or forced to go exile and being stripped of his status. The king is in no way permitted to use force against others or to instruct others to use force without the legitimate rulings of his counterpart authorities or unless proper to the law of his kingdom." ${ }^{\prime \prime}$

\footnotetext{
${ }^{12}$ Truth Publisher (1986), Marx/Engels, 45.

${ }^{13}$ See Pham Huy Chiem (1971), The Prince.

${ }^{14}$ Ibid.

${ }^{15}$ Dao Tri Uc 2006, 116-117.
} 
The Charter is said to be one of first written acts in the West that restricted the king's power, making him bounded by the law and forced to restrain from committing certain actions against the populace without legitimate rationales. These rationales can be found in the decisions of his counterparts or the law.

In the $17^{\text {th }}$ century, given the strong development of the capitalist relations of production, the idea of a state of law is heightened to a new level. The thinkers in this area resort to the idea of natural law to request more freedom and democracy for the people, affirm civil sovereignty, emphasize the role of the law, demand the state to be put under legal supervision and management and bounded by the law, and desire the laws to be in line with a human's natural rights. They argue that the state and law are not created by God, but rather by the conciliation between everyone with respect to a human's rationality. For them, the human being is endowed with certain inherent rights and obligations by its creator, which are associated with his birth and not dependent or given by the state, namely the right to live in freedom and equality, the pursuit of happiness and private ownership. On the other hand, the human being is obliged to refrain from causing damage to others and his community. The resulting demands of the human's will constitute the norms of natural law. "Human law" is supposed to be appropriate to "natural law", meaning the laws created by the state must be in conjunction with a human's intrinsic and natural rights. This idea is embedded in the works of such prominent scholars of this area as Grotius, John Locke, Montesquieu and Rousseau. Locke argues that as soon as he signs the contract to create a state, man has transferred the power to punish individuals to the state, whose authority is thus a congregation of individual power and results from the citizens; state power is limited or restricted by the stipulations of this contract, namely the preservation of freedom, property and life of each individual, but also of a society as a whole. To be sure, Locke's concept of state power resulting from citizens' power is a great scientific and political achievement, and is currently reflected in the constitutions of many contemporary states.

Locke compliments those institutions which are capable of ensuring human freedom, and also confirms that the first and foremost prerequisite is the separation or partition of powers. For him, in a republican state there are the legislative, executive and federative powers; all these powers are authorized to the state by popular will or in other words, the state is granted these powers by the people through a clearly defined agreement. Among these three, the legislative 
power is supposed to be highest as it is charged with creating mandatory pieces of legislation for every sector and every member of a society. Subsequent to the creation of these pieces, even the legislators are obliged to adhere to them; and the king, who holds the supreme executive or law enforcement power, has to abide by the law.

Locke strongly emphasizes the role of the law in state and social activities, and thus the respect for and compliance with the law by state bodies and personnel. Therefore, whatever leads to state disintegration is for him associated with a lack of respect for and compliance with the law by everyone, including most importantly the state bodies and those who are public authorities. $\mathrm{He}$ argues that whenever the legislative organs or the king or all of them violate the laws by, for instance, transgressing their authorized power or abusing power, interfering with the life, freedom and property of the people, state disintegration is likely to occur. This once again confirms that Locke is not only the author of the idea of state of law but also of the idea of separation of powers.

Montesquieu (1689-1755), one of the most prominent French enlighteners, in his famous work "The Spirit of the Laws", provides a definition of the law. He argues that humans are ruled by different kinds of law: natural law, divine law, religious law, international law, political law, civil law, family law, etc. Similar to Locke, Montesquieu is particularly concerned about protecting the freedom of citizens, as he argues that political freedom and civil safety and security can only be achieved with the absence of power abuse. To prevent the abuse of power it is necessary to create an appropriate mechanism to exercise state power. It is the separation of state power and mutual control between the branches of power. According to him, in every administration there are three branches of power: legislative power; the power to exercise that which is allowed by international law (executive power) and the power to perform that which is allowed by civil law (judicial power). Legislative power is the power to create temporary or permanent laws and amend or remove existing laws. Executive power is the power to decide matters regarding war and peace, send or receive ambassadors, increase common security and prevent possible invasive acts. Judicial power is the power to punish criminal acts or settle personal disputes between individuals. These three powers are supposed to be separated or granted to different actors in order to avoid the abuse or mistreatment of power, which ensures the freedom of citizens. For every human is born with the lust for power, he who has power is likely to abuse it. Whenever and wher- 
ever centralized power is given to a person or an organization, it is likely that it is abused. Montesquieu argues that the separation of state power can guarantee freedom because it prevents authoritarianism and mistreatment of power by the state. He also writes: "The freedom of citizens depends primarily on the validity of criminal laws. A vulnerable innocent citizen's security means the loss of freedom." 16 Therefore, charging a person as guilty must not merely be based on his thoughts, words or poems but on the consideration of his manifested actions. If his words are tied to actions, and his poems contain oppositional motives, then punishment is eligible and regulations must be created to protect his innocence if necessary.

Judging from the ideas of the above thinkers, it can be said that "the state of law" is mentioned by no one although its distinct signs are sketched out. In the $18^{\text {th }}$ century, Immanuel Kant (1724-1804) amended and developed the idea of state of law to a higher plane and Kant himself invented the concept of "state of law". For him, the state is an instrument that connects its member in a legal framework in order to supervise and ensure freedom and equality for every citizen. The state is responsible for addressing social disputes, monitor social relationships and making sure society is constantly improved for the sake of human interests. The state uses the law to assist every citizen in demonstrating his strength and maximizing individual labor and originality. Kant argues that to speak of the state means to speak of a state of law created by the people for the realization of freedom and equality. A person can pursue personal advancement according to his will if he keeps from violating the law. Every citizen is supposed to adhere to the law while enjoying the right and ability to put the state under the law. The state is tasked with protecting the laws and ensuring the reign of the law and freedom. That which promises to bring mutual relations between the state and its citizens is the separation of state powers which distinguishes between executive and legislative ones. ${ }^{17}$ Thanks to his ideas, Kant is perceived as one of the prominent theorists on the state of law a state that is based on individual autonomy and complies with the law in its every activity.

In conclusion, the idea of state of law has a long history which dates back to ancient times and develops alongside the progress of human civilization, re-

\footnotetext{
${ }^{16}$ See Montesquieu (1996), 119, 120.

${ }^{17}$ Nguyễn Văn Huyên (1996), 114.
} 
flecting aspirations of a state and an ideal social order which is capable of ensuring a free life and especially political freedom for everyone.

\section{The Conception and Basic Characteristics of the State of Law}

\section{The Concept of State of Law}

Since the $19^{\text {th }}$ century, the state of law has no longer just been an idea but has evolved into a civilized value of humankind, an ideal state model, an inevitable progress of all democratic states around the world, and a good reference model for the state shaping and development by contemporary nations. For one, until now, "the development of human civilization is for the most part regulated by the progress of civil society and state of law". ${ }^{18}$ State of law thus continues to be a widely researched subject in many countries such as Germany, Russia, the US and Vietnam that seek to grasp the characteristics of this model according to which they further improve their respective states. But what is the state of law? To this question different answers can be proposed, as the state of law is a complicated, multi-faceted phenomenon which can be viewed from different angles. This is better vindicated in the conceptions of state of law by contemporary scholars from different countries.

A number of German scholars claim that in modern languages there are two interchangeable concepts, namely the "state of law" (Rechtsstaat, état de droit) and the "rule of law", depending on each particular language. These two in fact share both similar and different points. What they have in common is that both "state of law" and „rule of law" originate from some basic principles: the universality of legal norms, the public nature of law and the non-retroactiveness and transparency of legal norms. The difference is that "rule of law" is used according to English common law, which puts more emphasis on popular participation in an organized political progress without specifying the state's role. On the other hand, "state of law" refers to a specific role of a state, the state, i.e. its real components.

Nevertheless, it is argued by some authors that "the rule of law" is not correctly the equivalent of "nhà nước pháp quyền" in Vietnamese. For one thing, "the rule of law" refers to a society managed and run on the basis of clearly

\footnotetext{
${ }^{18}$ Vietnam Academy of Social Sciences (1991), 5.
} 
identified rights as indicated by human law and natural law, so that the subjects can exercise their rights at their will to improve happiness without violating others' rights; every subject, even the state, has to station itself below the law. The "rule of law" is therefore not simply a state of law, although it still plays an important part. ${ }^{19}$ Accordingly, I recommend translating "the rule of law" as "chế độ pháp quyền" instead of "chế độ pháp trị” (which may be translated into English as "rule by law"), as it refers to a higher process compared to "state of law".

Scholars have different definitions of the state of law. Some authors conceptualize state of law as a state that recognizes and respects the supremacy of the law, makes clear distinctions between the legislative, executive and judicial branches which are mutually controlled and managed, ensure that its citizens enjoy full legal safety and their basic liberal rights are protected, and fulfill international agreements. ${ }^{20}$ Another definition says that the "state of law regulates both society and itself according to the law, and the state apparatus is inferior to the law." 21 Another line of thought says that state of law is not a specific kind of state but a state model wherein general and particular characteristics coexist and the concept of state of law must be understood in both dimensions: as a general characteristic of the state as a special organ of political power, and a particular characteristic of state as part of a triangle made by the state-the law-civil-society. ${ }^{22}$. Other scholars argue that the state of law is a form of state as its organization and operations are in contrast with those of authoritarian and dictatorial states; in contrast to those of states that are organized by humanism and also those states that follow legalism. ${ }^{23}$

In addition, there are other conceptions of the state of law. Although the conceptions of the state of law are different from scholar to scholar, they share the following common points when contrasting it with authoritarian and totalitarian states or non-state of law:

- First, the state of law is legally founded and its power and operations are limited by the law, based on the law and the idea of justice; it must be con-

\footnotetext{
${ }^{19}$ See Nguyen Dang Dung (2007).

${ }^{20}$ Nguyen Duy Quy/Nguyen Tat Vien (2008), 150.

${ }^{21}$ Nguyen Duy Quy/Nguyen Tat Vien (2008), 150.

${ }^{22}$ Nguyen Duy Quy/Nguyen Tat Vien (2008), 151.

${ }^{23}$ Nguyen Duy Quy/Nguyen Tat Vien (2008), 151-152.
} 
trolled by the law; the state is utilized to protect individual freedom and protecting civil interests is its raison d'être.

- Second, the state of law has an advanced legal system which is based on and relevant to a human's natural rights, respects and guarantees the implementation of human rights, civil rights and freedom, and manages to remove authoritarianism, exclusiveness and government's arbitrariness.

- Third, this legal system retains its superiority and is applied equally nationwide; every subject, even the state, is obliged to obey the law and pursue justice, respect human rights and individual freedom. State organization and operations are completely based on legal regulations in order to fulfill these regulations.

- Fourth, the court of law is independent and its rulings must be in conjunction with constitutional principles. It is supposed to safeguard the rights of the people against the violation of any other subject, including the state, and it is followed by all subjects, not excluding state organs.

The above analysis helps us confirm that state of law is first and foremost a state in its fullest sense - an organization that holds political power or a public authority endowed with state characteristics. However, it is not a socioeconomic form in the sense of a feudal state or capitalist state, but a state whose organizational structure and operations are different from those of authoritarian or dictatorial states in that it is not an instrument of social and human suppression but one of social benefaction. It does not tamper with individual liberty but serves the public interest, individual freedom and social justice. It is organized and run on the basis of civil sovereignty and separation of powers, as the state and other social subjects always observe and fulfill the law in their behaviors. It is a democratic, just and transparent system that reflects the will of the populace, runs on the basis of and with regard to human's natural rights, respects human basic rights and mutual responsibility between various subjects.

In conclusion: The state of law is a state that is organized and run on the basis of civil sovereignty, the separation of powers and a democratic, transparent and advanced legal system. It is an instrument for the guarantee of individual freedom, social justice and the supremacy of law in state and social activities. 


\section{The Basic Features of the State of Law}

The above definition of the state of law indicates that apart from the general features, the state of law also possesses these basic characteristics:

First, the state of law is organized and functions on the basis of civil sovereignty.In authoritarian and dictatorial states, the people are always expected to be ruled and suppressed, and can never be said to hold state power but only be subject to it. Whereas in the state of law, the entire state power belongs to them, as they are its highest and sole holders. The people are believed to participate in state activities and supervise the state officials and organs by themselves or through their representatives. They make the supreme and ultimate decisions on the matters pertaining to national being and sovereignty and other important state affairs. Therefore, the state has to serve the interests of its people, and its every policy is supposed to derive from popular demands and interests and serves to meet their appropriate aspirations. The people's sovereignty and various measures to exercise it must be indicated in the Constitution, which is the state's fundamental and original piece of legislation. For example, the current Vietnamese Constitution emphasizes: the State belongs to the People, by the People, for the People; all state power belongs to the People; the People exercise their state power through direct democracy or representative democracy through the National Assembly, People's Councils and through other State organs. The German Constitution also remarks: "All public power derives from the people. They perform this power through elections and public polls as well as through particular legislative, executive and judicial powers." 24

Second, in the state of law, human rights and civil rights are respected and protected. It can be said that the idea of state of law has its origin from the desire and demand to restrain and control state power in order to ensure individual freedom. Thus, "Freedom, equality, human dignity and other manifestations of human rights assurance are the lasting features of the state of law." 25 The relationship between the state of law and its citizens is based on equality, which means that either side has its rights and obligations in relation to the other. The citizens have both rights and obligations towards the state and vice versa. For this reason, civil freedom is at the same time the limitation of state

\footnotetext{
${ }^{24}$ Konrad-Adenauer-Stiftung (2002), 88.

${ }^{25}$ Konrad-Adenauer-Stiftung (2002), 51.
} 
power, civil rights are contrary to state rights and citizens' range of freedom is larger than that of the state. While citizens are allowed to do whatever the law does not forbid, state organs and employees are restricted to act within what the law allows. In a state of law, the basic and sacred human rights such as the right to live, to be free and to pursue happiness are expected to be fulfilled because they are acknowledged by the law and ensured; the legitimate rights and benefits, honor and dignity of every citizen are guaranteed and protected by the state through the law. Theoretically, the state of law has to make sure that every individual is equal and free before the law and is provided with ample legal conditions to pursue his personal growth with ease, so that every individual can make the best use of his intrinsic capacity. The fairness and equality among citizens in the state of law are ensured not only in legal terms but also in practice, as the state guarantees every necessary material and spiritual condition for the citizens to exercise them in practice. In addition, the state protects individual freedom from the violation of other actors, including the state organs. Citizens have the rights to replace the authorities should they violate their legitimate rights and interests, to oppose any arbitrary and illegal intervention by the authorities and, at the same time, are obliged to respect and follow the law and fulfill their legal tasks with regard to the state and other actors. In general, in the state of law, the state-individual relationship is directed in a way in which

"The state is a coalition of the masses under the control of the law; humans can in no way be regarded as a means to an end, rather, humans must be an end in itself; every individual and a society as a whole have to respect and protect the law; each citizen is granted the right and ability to pressure those who hold power to respect and adhere to existing laws. ${ }^{26}$

Third, the state of law is a democratic state. The state of law uses law for social management and functions both publicly and democratically. The formal manifestation of democracy in the state of law is that state power stems from its citizens and is authorized by the citizens to the state; therefore it is restricted within the authorized range and by the law. Society is regulated by law and citizens are able to participate in social development, in human rights protection, in economic development and in the assurance of social justice. Democracy and laws are crucial to development and are held in high regard by national

${ }^{26}$ Nguyen Van Dong (1996), 21. 
decision-makers. ${ }^{27}$ The state of law has the full capacity to establish, consolidate and protect democracy. Through the law, the state acknowledges freedom and democracy in every civil sector; acknowledges the intervention in state and social management by social organizations and popular unions; regulates the authority of state organs to restrict their power and keep them from violating civil democracy and freedom. Through the law, the state ensures the implementation of civil rights, preventing illegal acts and creating punitive measures against any actor that violates the legitimate rights and interests of its citizens, so that the established democracy is protected.

Fourth, the state of law has a democratic and transparent legal system which reflects the popular will appropriate to national circumstances and holds the highest position in public and social life. The law can be said to be indispensable to the creation of a state of law but not every legal system is adequate enough to be the law of such a state. Such a legal system has to be democratic, transparent and in conjunction with existing conditions of the country such as its socio-economic level of development, morality, customs, history and traditions, culture, psychological features, international and transnational law which have been recognized or signed by the state. This legal system has to reflect the will of the people, recognize basic human rights, civil sovereignty and mutual responsibility among the subjects. The law of a state of law is supposed to have a universal effect on everyone and their behaviors, and is stable enough to help the subjects anticipate the consequences of their behaviors or the response of the state and other subjects. According to the law, as citizens are held responsible before the state, the state also has responsibilities before its citizens should it violate their legitimate rights and interests; mutual responsibilities are expected of each subject which is involved in legal relations if it violates the interests of other subjects. The democracy of a legal system is reflected not only in its regulations but also in the development of the laws which is expected to conform to popular will. The legal regulations have to be clear and specific and widely and publicly announced so that anyone is able to refer to them to protect his rights. Such a legal system must have feasibility and is primarily reflected in the acts that are developed by capable legislators, among which the constitution is most revered legally. For this reason, the legal

${ }^{27}$ Nguyen Duy Quy/Nguyen Tat Vien (2008), 55. 
systems of former slavery and feudalistic states are impossible to be rendered as a state of law as they do not meet the above criteria.

The state of law implies that its power or strength resides in the law and the law's supremacy is what constitutes a state of law, so the respect of and compliance with the law is its intrinsic component. The state-law relationship in a state of law is mutual and interactive. Despite being drafted by the state, as long as it takes effect, the law returns to bind the state and becomes the legal framework for the entire organization and functioning of the state apparatus and also a means to restrain and limit state power. The law regulates the establishment, organizational structure, functions, missions and rights of each state organ of every kind and level; standardizes the relations between state organs and between the internal components of an organ. The organization and activities of state apparatus are based on the law and performed within the legal framework for legal purposes. The law becomes a conduit through which the state conveys its will and fulfills its purposes. All state organs and employees have to maintain absolute compliance with the law in their behaviors and are only allowed to do what it permits. They are kept from applying the law in an arbitrary way and instead have to follow the regulated principles and procedures. The state itself should provide necessary institutions and mechanism to supervise its compliance such as the constitutional court, judicial independence, popular supervision and other watchful organizations in the political system. Any state organ or employee who violates the law has to deal with legal responsibility and has to compensate if any individual interest is damaged. The law not only holds a supreme position in the political realm but also in social life. All non-governmental entities and individuals, although permitted to do what the law does not forbid, are obliged to respect and conform to the law and face legal responsibility should they violate it. The essential domination of the law over the state and society is reflected in Locke's remarks:

"Even though the government holds all the rights, because these rights only live to serve social interest and cannot be used arbitrarily and randomly, they must be implemented through the existing and established acts, so that both sides have their responsibilities and safety within the law and even rulers have to be restricted in an adequate range. ${ }^{228}$

${ }^{28}$ Konrad-Adenauer-Stiftung (2002), 166. 
Fifth, the state of law is organized and functions based on the separation of powers as a means to check and control power. In other words, the state of law is organized and functions in line with the management of state power. Separation of state power is one of the initial features of the state of law. Its aim is to prevent any centralized state power in the hands of an individual or state organ, so that authoritarianism and power abuse can be minimized while state power is performed. The separation allows for the restraining and management of state power and anticipating the behaviors of the government. In a state of law, state power is basically divided into three branches: legislative, executive and judicial branches. Each function is primarily transferred to a state organ. All these functional organs are established based on the purpose and regulations of the law. The constitution endows each organ with a specific set of rights and regulates the mutual relationship between them. As a result, each state organ is able to not only maintain its independent and specialized activities and prevent and restrain other organs so that state power can be limited and controlled, but can also coordinate with other organs to form unity within the state apparatus. This facilitates the effective performance of each state organ and the entire state apparatus. In the practice of organizing state power, legislative power reflects the popular will through the law and is conferred to a congress or parliament. Executive power, which embodies the power to exercise the will of an entire nation through the practical application of the pieces of legislation, is given to the government. Judicial power, the power to judge unconstitutional and unlawful behaviors and to solve civil disputes that threatens justice, civil freedom and social order and safety, is given to the court. The law provides a firm mechanism that involves these three branches in mutual control and checking while also allowing for coordination among them to avoid the abuse of power, maintain the unity of state power and increase the performance of the state apparatus.

Sixth, the state power is closely associated with civil society. The state of law must be developed on the basis of a close relationship with civil society. In a modern sense, civil society is perceived as a relatively autonomous sector in relation to the state, in which social groups and cultural, religious and spiritual organizations exist and function to serve different human interests. ${ }^{29}$ Simply put, civil society is composed of non-state and apolitical organizations, and its

${ }^{29}$ Nguyen Duy Quy/Nguyen Tat Vien (2008), 61-62. 
existence signifies a social sector that is not necessarily dominated by state power. As a social value, civil society indicates a society's innate ability to allow its citizens to establish their organizations to fulfill the aspirations of their members and realize the general social objectives. As an institution, civil society is considered a social entity that exists among the state, families and individuals. $^{30}$ Through legal mechanisms, the state regulates the rights and legal responsibilities of itself, individuals and non-state organizations so as to ensure the existence and functioning of civil society.

The basic features of the state of law are sketched out above. However, depending on each particular state of law, there are other particular and idiosyncratic signs and features. As historical analysis has shown, the idea of the state of law can stem from different socio-economic forms even if it is universally used and results in different interpretations and actualizations depending on social and class interests, national traditions, cultural level and other factors. A prominent division in reality has been the capitalist state of law and socialist state of law. The capitalist state of law is currently developed in most of the developed and developing capitalist nations. The socialist state of law is in the making in Vietnam, a nation that currently advances its society towards socialism. This stems from the fact that although the state of law itself is a universal idea, there is no absolute model for every state and nation. Rather, depending on its historical, political, socio-economic features and level of development, each state or nation develops its own state of law model and opts for a particular method of constructing and running its state of law. However, each particular state of law is supposed to hold universal features and worldwide values of the state of law, and at the same time reflect its particular attributes and the idiosyncrasies of its nation and people. For example, the socialist state of law not only has the said general features but also other particular attributes such as its socialist-based economic relations and its being led by a communist party. In contrast, the capitalist state of law is built on an economic basis formed by capitalist relations of production and is under the leadership of a capitalist party or a coalition of capitalist parties.

${ }^{30}$ Nguyen Duy Quy/Nguyen Tat Vien (2008), 62. 


\section{References}

Dao Tri Uc (ed.) (2006): The Organization and Functioning of the Vietnamese Socialist State of Law (Mô hình tổ chức và hoạt động của Nhà nước pháp quyền xã hội chủ nghĩa Việt Nam). Hanoi.

Ellis, William (ed.) (1941): The Politics of Aristotle or A Treatise on Government. London.

Konrad-Adenauer-Stiftung (ed.) (2002): The State of Law. Hanoi.

Lã Trấn Vũ (1964): History of Chinese Political Ideas. Hanoi.

Luu Kien Thanh/Pham Hong Thai (eds.) (1993): History of the World Historical Theories (Lịch sư các học thuyết chính trị trên thế giới). Hanoi.

Nguyen Dang Dung (ed.) (2007): Vietnam National Assembly on the State of Law (Quốc hội Việt Nam trong Nhà nước pháp quyền). Hanoi.

Nguyen Duy Quy/Nguyen Tat Vien (eds.) (2008): The Socialist State of Law of Vietnam of the People, by the People, for the People - Theoretical and Practical issues (Nhà nước pháp quyền xã hội chủ nghĩa Việt Nam của dân, do dân, vì dân-lí luận và thực tiễn). Hanoi.

Nguyen Van Dong (1996): Theories on the State of Law - Historical and Contemporary Issues (Học thuyết về nhà nước pháp quyền-Lịch sử và hiện tại). Journal of Legal studies, issue no 4/1996. 21.

Nguyễn Văn Huyên (1996): Immanuel Kant Philosophy (1724-1804) (Triết học Imanuin Cantơ). Hanoi.

Pham Huy Chiem (ed.) (1971): The Prince by Machiavelli (Vietnamese Translation). Saigon.

Phan Ngoc (ed.) (2001): Han feizi of hanfei. Hanoi.

Montesquieu, Charles-Louis de Secondat de (1996): The Spirit of the Laws. Hanoi.

Thích Mãn Giác (1967): History of Indian philosophy. Saigon.

Truth Publisher (ed.) (1986): Karl Marx/Friedrich Engels. Collected Works. Third Volume (Vietnamese edition). Hanoi.

Vietnam Academy of Social Sciences (1991): The State of Law and Civil Society (Nhà nước pháp quyền và xã hội công dân). Hanoi.

VNU Press (ed.) (2009): The History of Political Theories (Giáo trình Lịch sử các học thuyết chính trị). Hanoi. 